chạy thận nhân tạo (OR 4,697; 95\%CI 1,068 20,665); Tổn thương sùi > $30 \mathrm{~mm}$ (Ỏ 13,754; $95 \%$ CI 1,832 - 103,250).

Nghiên cứu của nhóm tác giả Jiwon Hwang ở đại học Sungkyuwan ghi nhận độ tuổi, phương pháp điều trị và nhiễm khuẩn chủng S.aureus kháng methicillin là các yếu tố liên quan độc lập đến tỷ lệ tử vong/ tái nhập viện ở các bệnh nhẩn viêm nội tâm mạc nhiểm khuẩn cộng đồng $(p<0,05)$. Giá trị OR hồi quy đa biến có ý nghĩa thông kê: Tuổi (OR 1,04; 95\%CI 1,01-1,07); Bênh nhân không được phẫu thuật dù có chỉ định (OR 29,83; 95\%CI 10,19 - 87,31); Nhiễm khuẩn chủng S.aureus kháng methicillin ( $\mathrm{OR}$ 9,58; 95\%CI 2,27-40,45).

\section{KẾT LUÂNN}

- Tỷ lệ tử vong chung của bệnh nhân VNTMNK sau 6 tháng theo dõi là 25,4\% (32 bệnh nhân), trong đó tỷ lệ tử vong trong bệnh viện là $10,3 \%$ (13 bệnh nhẩn).

- Các yếu tố tiên lượng độc lập với tăng tỷ lệ tử vong của bệnh nhân gồm: số lượng bạch cầu tăng; nồng độ ure và creatinin máu tăng; mức lọc cầu thận giảm; điều trị phẫu thuật sớm làm giảm tỷ lệ bệnh nhân tử vong $(p<0,05)$

\section{TÀI LIẸU THAM KHẢO}

1. Habib G, Lancellotti $P$, Antunes MJ, et al. 2015 ESC Guidelines for the management of infective endocarditis: The Task Force for the Management of Infective Endocarditis of the European Society of Cardiology (ESC)Endorsed by: European Association for Cardio-Thoracic Surgery (EACTS), the European Association of Nuclear
Medicine (EANM). Eur Heart J. 2015;36(44):30753128. doi:10.1093/eurheartj/ehv319

2. Sci-Hub | Infective Endocarditis in Adults: Diagnosis, Antimicrobial Therapy, and Management of Complications. Circulation, 132(15), 1435-1486 | 10.1161/ CIR.0000000000000296. Accessed October 24, 2021. https://sci-hub.se/ 10.1161/ CIR.0000000000000296

3. Wu Z, Chen $Y$, Xiao $T$, Niu $T$, Shi $Q$, Xiao $Y$. Epidemiology and risk factors of infective endocarditis in a tertiary hospital in China from 2007 to 2016. BMC Infect Dis. 2020;20(1):428. doi:10.1186/s12879-020-05153-w

4. Chu VH, Cabell CH, Benjamin DK, et al. Early predictors of in-hospital death in infective endocarditis. Circulation. 2004;109(14):1745-1749. doi:10.1161/01.CIR.0000124719.61827.7F

5. Li JS, Sexton DJ, Mick N, et al. Proposed modifications to the Duke criteria for the diagnosis of infective endocarditis. Clin Infect Dis Off Publ Infect Dis Soc Am. 2000;30(4):633-638. doi: $10,1086 / 313753$

6. Nguyễn Thị Thu Hoài. Viêm nội tâm mạc nhiễm khuân tại Bệnh viện Bạch Mai, 2012 - 2017. 2019. Published online 2019.

7. Siciliano RF, Gualandro DM, Bittencourt MS, et al. Biomarkers for prediction of mortality in leftsided infective endocarditis. Int J Infect Dis IJID Off Publ Int Soc Infect Dis. 2020;96:25-30. doi:10.1016/j.ijid.2020.03.009

8. Ortega-Loubon C, Muñoz-Moreno MF, Andrés-García $I$, et al. Nosocomial Vs. Community-Acquired Infective Endocarditis in Spain: Location, Trends, Clinical Presentation, Etiology, and Survival in the 21st Century. J Clin Med. 2019; 8(10):E1755. doi:10.3390/jcm8101755

9. Wu Z, Chen Y, Xiao T, Niu T, Shi Q, Xiao Y. Epidemiology and risk factors of infective endocarditis in a tertiary hospital in China from 2007 to 2016. BMC Infect Dis. 2020;20(1):428. doi: $10.1186 / \mathrm{s} 12879-020-05153-w$

\title{
CÁC YẾU TỐ TIÊN LƯỢNG BÊ̂NH LAO MÀNG NÃO TRẺ EM TẠI BỆNH VIỆN NHI TRUNG ƯO'NG
}

\section{TÓM TẮT}

Bệnh lao là một nguyên nhân quan trọng gây ra bệnh tật ở trẻ em. Lao màng não là thể lao nặng, có nguy cở tử vong hoặc để lại di chứng nặng nề. Mục tiêu: Tìm hiểu một số yếu tố tiên lượng của Lao màng não ở trẻ em tại BV Nhi TW. Đối tượng, phương pháp nghiên cứu: Nghiên cứu mô tả cắt ngang, kết hợp hồi cứu và tiến cứu tất cả các bệnh nhân được

*Bênh viên Nhi Trung ương

Chịu trách nhiệm chính: Nguyễn Văn Lâm

Email: nguyenvanlam73@gmail.com

Ngày nhận bài: 20.9.2021

Ngày phản biên khoa hoc: 10.11.2021

Ngày duyệt bài: 22.11.2021

\section{Nguyễn Phương Thảo*, Nguyễn Văn Lâm*}

chẩn đoán lao màng não tại BV Nhi TW từ tháng 06/2015 đến tháng 5/2021. Kết quả: có 125 bệnh nhân lao màng não trong 6 năm từ tháng 06/2015 đến tháng $5 / 2021$, tuổi mắc bệnh chủ yếu dưới 5 tuổi (81\%), tỷ lệ nam/nữ là $1,6: 1$; tiếp xúc với nguồn lây lao $(55,6 \%)$. Thời gian từ khi có triêu chứng đến kh chẩn đoán trung bình là 25 ngày. Triệu chứng thường gặp nhất là sốt $(98 \%)$, gây sút cân $(52 \%)$; co giật (47\%), tăng trương lực cơ (56\%), dấu hiệu màng não (71\%), liệt thần kinh sọ $(35,2 \%)$, tỷ lệ các mức độ nặng (theo BMRC) I, II, III tương ứng 22,4\%, 38,4\%, $39,2 \%$. Số lượng tế bào DNT < $100 \mathrm{BC} / \mathrm{ml}$ chiếm $53,6 \%$, protein dịch não tủy trung vị $2 \mathrm{~g} / \mathrm{l}$ (tứ phân vị: $1,4-3,8)$; Natri máu giảm chiếm $(87,2 \%)$. Tỷ lệ nuối cấy và PCR lao dương tính trong DNT là $(70,4 \%)$. Tổn thương trên MRI sọ não $(85,5 \%)$, giãn não thất 
(80\%). Chậm trễ chẩm đoán, mức độ nghiêm trọng trên lâm sàng lúc chẩn đoán, tình trạng tăng trướng lực cơ là yếu tố tiên lượng tử vong. Tuổi < 5, chậm trê chẩn đoán, mức độ nghiêm trọng trên lâm sàng, tăng trương lực cơ, mức độ giảm Natri máu, giãn não thất có liên quan đến tăng nguy cơ kết hợp di chứng thần kinh hoặc tử vong. Kết luận: Viêm màng não do lao ở trẻ em tại Bệnh viện Nhi trung ương gặp nhiều ở trẻ క 5 tuổi, có tỷ lệ tử vong và di chứng đáng kể. Chậm trễ trong chẩn đoán, tình trạng tăng trương lực cớ, mức độ nghiêm trọng trên lầm sàng (theo $\mathrm{BMRC}$ ), tăng trương lực cớ, mức độ giảm Natri máu, giãn não thất là các yếu tố tiên lượng tử vong và di chứng thần kinh. lượng.

Tư khóa: lao màng não, lao trẻ em, yếu tố tiên

\section{SUMMARY \\ PROGNOSTIC FACTORS OF TUBERCULOUS MENINGITIS IN CHILDREN IN VIETNAM} NATIONAL CHILDREN'S HOSPITAL

Tuberculosis (TB) is an important cause of childhood morbidity. Tuberculous meningitis (TBM) is a severe form of tuberculosis, which can cause serious complications and death. Purpose: Research prognostic factors of children with meningeal tuberculosis in Vietnam National Children's Hospital (Vietnam NCH). Methods: A cross-sectional desciptive study of all patients who were diagnosed with TBM at Vietnam NCH. Results: There were 125 patients with menigeal tuberculosis in 6 years from June 2015 to May 2021 , age of mainly under 5 years old $(81 \%)$, male / female ratio is 1.6: 1 ; exposed to TB $(55,6 \%)$. The average time from symptom to diagnosis was 25 days. The most common symptoms were fever $(98 \%)$, weight loss (52\%); convulsions $(47 \%)$, hypertonia (56\%), meningeal signs $(71 \%)$, cranial nerve paralysis $(35,2 \%)$, MRC grade (United Kingdom Medical Research Council criteria) I, II, III corresponding to $22,4 \%$, $38,4 \%, 39,2 \%$. Number of CSF cells were of less than 100 per ml, median of CSF protein concentration was of $2 \mathrm{~g} / \mathrm{l}$ (quarter range: $1,4-3,8$ ). Hyponatremia was in $87,2 \%$ of the patients. Positive TB culture and positive PCR result from CSF were $70,4 \%$. Abnormalities on cerebral MRI were 85,5\%, including ventricular dilatation (80\%). Delayed treatment, more severe MRC grade, hypertonia were prognostic factors for mortality; Aged $\leq 5$ years, Delayed treatment, more severe MRC grade, hypertonia, degree of hyponatremia, hydrocephalus were associated with mortality or the combined endpoint. Conclusions: Tuberculous meningitis in children at the National Children's Hospital is common in children $\leq 5$ years old, with significant mortality and sequelae. Delayed treatment, more severe MRC grade, hypertonia, degree of hyponatremia, hydrocephalus are prognostic factors of mortality and neurological sequelae.

Keywords: Tuberculous meningitis, Children, prognostic factors.

\section{I. ĐẶT VẤN ĐỀ}

Hiện nay bệnh lao vẫn còn là nguyên nhân gây tử vong đứng hàng thứ 2 trong các bệnh nhiễm trùng, với khoảng 10 triệu bệnh nhân lao mới hàng năm và khoảng 1,4 triệu người tử vong do Lao trên toàn cầu. Việt Nam đứng thứ 16 trong số 30 nước có gánh nặng bệnh lao cao nhất thế giới và xếp thứ 15 về lao kháng đa thuốc [1]. Lao màng não là là bệnh nhiễm trùng thần kinh trung ương do trực khuẩn Mycobacterium Tuberculosis gây ra, một trong những thể bệnh hay gặp trong nhóm mắc lao trẻ em, chiếm khoảng $5 \%$ các ca bệnh lao ngoài phổi và tỷ lệ mắc cao nhất ở trẻ dưới 4 tuổi. Lao màng não còn là một trong những thể lao nặng nhất, tiên lượng xấu, tỷ lệ tử vong và di chứng thần kinh cao [2].

Thách thức trong chẩn đoán và điều trị lao trẻ em là rất lớn. Triệu chứng ban đầu ở trẻ nhỏ không đăc hiệu, khó khăn trong lấy mẫu bệnh phẩm để chẩn đoán, các mẫu bệnh phẩm thu được thường cho khả năng tìm được vi khuẩn lao thấp. Tỷ lệ tử vong và di chứng nặng có liên quan đến việc chậm chễ trong chẩn đoán và điều trị [3]. Việc cải thiện kết quả điều tri phụ thuộc vào sự tăng cường hiểu biết về dịch tễ học của bệnh lao ở trẻ em, chẩn đoán sớm, tiển lượng chính xác và phác đồ điều trị có hiệu quả.

Vì vậy chúng tôi tiến hành nghiên cứu này với mục tiêu: Tim hiểu một số yếu tố tiên lượng của Lao màng não ở trẻ em tại Bệnh viện Nhi Trung ương.

\section{II. ĐỐI TƯỢNG VÀ PHƯƠNG PHÁP NGHIÊN CỨU}

2.1. Đối tượng nghiên cứu: Gồm 125 bệnh nhân nhi từ 2 tháng đến 15 tuổi được chẩn đoán lao màng não điều trị tại Bệnh viện Nhi Trung ương từ tháng 06/2015 đến tháng 5/2021.

2.2. Tiêu chuẩn chọn bệnh nhân nghiên cứu. Tất cả các bệnh nhân nhân từ 2 tháng đến 15 tuổi được chẩn đoán lao màng não điều trị tại Bệnh viện Nhi Trung ương theo Hướng dẫn chẩn đoán, điều trị và dự phòng bệnh lao của Bộ Y tễ năm 2018 [4].

\subsection{Phương pháp nghiên cứu}

\subsubsection{Thiêt kê nghiên cứu:}

Nghiên cứu mô tả cắt ngang, kết hợp hồi cứu và tiến cứu

+ Giai đoạn hồi cứu: từ tháng 06/2015 đến tháng $5 / 2020$

+ Giai đoạn tiến cứu: từ tháng 6/2020 đến tháng $5 / 2021$

2.3.2. Cỡ mẫu: Chọn mẫu thuận tiện (mẫu toàn bộ)

2.2.3. Nội dung nghiên cứu: Theo mẫu bệnh án thiết kế sẵn

2.3.4. Phân tích số liêu: Số liệu sau khi được thu thập sẽ dược mã hóa theo mẫu, nhập 
số liệu và phân tích số liệu bằng phần mềm SPSS 20.0 .

\section{KẾT QUẢ NGHIÊN CỨU}

Trong thời gian 6 năm từ tháng 01/06/2015 đến 31/05/2018 chúng tôi có 125 bệnh nhân được chẩn đoán lao màng não đủ tiêu chuẩn lựa chọn vào nghiên cứu.

3.1. Đặc điểm nhân khẩu học và lâm sàng: - Tỷ lệ nam/ nữ = 1,6/1; nam giới (61\%)

- Tuổi: Bệnh thường gặp ở trẻ dưới 5 tuổi, chiếm tỷ lệ $81 \%$; tuổi trung vị 19 tháng, khoảng tứ phân vị $9-44$ tháng.

- Bệnh nhân có tiền sử tiếp xúc nguồn lây chiếm $55,6 \%$.

- 29\% bệnh nhân không được tiêm phòng vaccine lao.

- Đa số bệnh nhân được chẩn đoán muộn, thời gian từ khi có triệu chứng lâm sàng đến khi chẩn đoán thường trên 2 tuân (76\%). Thời gian nhập viện trung bình là $25 \pm 14$ ngày.

- Có 45/126 (chiếm 36\%) bệnh nhân được chẩn đoán và điều trị tại cơ sở y tế mà không được xác định có nhiếm trùng hệ thần kinh trung ương. Bệnh nhân được khám và điều trị tại các chuyên khoa Phục hồi chức năng (chẩn đoán Vẹo cổ), Ngoại thần kinh (chẩn đoán Não úng thủy bẩm sinh, U não), Cấp cứu chống độc (Hạ Natri máu, ngộ độc chì), Răng hàm mặt (Viêm hạch cổ).

Bảng 1: Đặc điểm lâm sàng bệnh nhân lao màng não

\begin{tabular}{|c|c|c|}
\hline Triệu chứng & $\begin{array}{c}\text { Số beênh } \\
\text { nhẩn } \\
(\mathbf{n = 1 2 5 )}\end{array}$ & $\begin{array}{c}\text { Tỷ lệ } \\
\mathbf{( \% )}\end{array}$ \\
\hline Sốt & 123 & 98,4 \\
\hline
\end{tabular}

\begin{tabular}{|c|c|c|c|}
\hline \multicolumn{2}{|c|}{ Ra mồ hôi trộm } & 62 & 49 \\
\hline \multicolumn{2}{|c|}{ Gầy sút cân } & 65 & 52 \\
\hline \multicolumn{2}{|c|}{ Hạch ngoại biên } & 24 & 19 \\
\hline \multicolumn{2}{|c|}{ Đau đâu, quấy khóc } & 100 & 80 \\
\hline \multicolumn{2}{|c|}{ Buồn nôn, nôn } & 95 & 76 \\
\hline \multicolumn{2}{|c|}{ Co giật } & 59 & 47 \\
\hline \multicolumn{2}{|c|}{ Cơn tăng trương lực cơ } & 70 & 56 \\
\hline \multicolumn{2}{|l|}{$\mathrm{Ho}$} & 27 & 21,6 \\
\hline \multicolumn{2}{|c|}{ Dấu hiệu màng não } & 89 & 71 \\
\hline \multirow{3}{*}{$\begin{array}{l}\text { Mức độ nghiêm } \\
\text { trọng trên lâm } \\
\text { sàng* (Độ MRC) }\end{array}$} & Độ I & 28 & 22,4 \\
\hline & Độं II & 48 & 38,4 \\
\hline & Độ III & 49 & 39,2 \\
\hline \multirow{2}{*}{ Biểu hiện liệt } & $\begin{array}{c}\text { Liệt nửa } \\
\text { nqười }\end{array}$ & 42 & 33,6 \\
\hline & $\begin{array}{l}\text { Liệt thân } \\
\text { kinh so }\end{array}$ & 44 & 35,2 \\
\hline
\end{tabular}

*Phân loại độ nặng lao màng não theo hội đồng nghiên cứu y khoa Anh (British Medical Research Council criteria - BMRC) [5]

Sốt, nôn và đau đầu/ quây khóc là những triệu chứng thường gặp nhất. Co giật được ghi nhận ở 59 trường hợp (47\%). Các dâu hiệu màng não gặp ở đa số bệnh nhân $(71 \%)$, bao gồm các dấu hiệu: cổ cứng, thóp phồng, Kernig, vạch màng não, tăng cảm giác đau, sợ ánh sáng. Các triệu chứng gợi ý tổn thương nhu mô não như giảm tri giác (mức độ lâm sàng II, III) $(77,8 \%)$, phân chia theo mức độ nghiêm trọng trên lâm sàng theo thang điểm MRC cho thây các mức độ MRC I, II, III tương ứng là $22,4 \%$, $38,4 \%, 39,2 \%$, tăng trương lực cơ liên tục hoặc thành cơn $(65 \%)$, rối loạn cơ tròn thường là tạm thời có hồi phục, liệt nửa người khá thường gặp $(33,6 \%)$, liệt thần kinh sọ là tổn thương đặc hiệu cho tổn thương não do lao chiếm 35,2\%.

\section{2. Đặc điểm cận lâm sàng}

\begin{tabular}{|c|c|c|c|}
\hline \multicolumn{2}{|c|}{ Đăc điểm } & Số bệnh nhân (n=125) & Tỷ lệ (\%) \\
\hline \multirow{4}{*}{ Protein $(\mathrm{g} / \mathrm{l})$} & $0,5-1$ & 19 & 15,2 \\
\hline & $1-3$ & 69 & 55,2 \\
\hline & $>3$ & 39 & 29,6 \\
\hline & Trung vị, khoảng tứ phân vị & \multicolumn{2}{|l|}{$2(1,4-3,8)$} \\
\hline \multirow{2}{*}{$\begin{array}{c}\text { Đường } \\
\text { (mmol/l) }\end{array}$} & Giảm $(<2,2 \mathrm{mmol} / \mathrm{l})$ & 92 & 73,6 \\
\hline & Bình thường & 33 & 26,4 \\
\hline \multirow{3}{*}{$\begin{array}{l}\text { Muối clo } \\
\text { (mmol/l) }\end{array}$} & Giảm (<120mmol/l) & 106 & 84 \\
\hline & Bình thường & 19 & 16 \\
\hline & Trung vị, khoảng tứ phân vị & \multicolumn{2}{|l|}{$114(106-118)$} \\
\hline \multirow{4}{*}{$\begin{array}{l}\text { Tế bào (tế } \\
\text { bào /ml) }\end{array}$} & $\leq 100$ & 67 & 53,6 \\
\hline & $101-500$ & 48 & 38,4 \\
\hline & $>500$ & 10 & 8 \\
\hline & Trung vị, khoảng tứ phân vị & \multicolumn{2}{|l|}{$100(40-218)$} \\
\hline \multirow{2}{*}{$\begin{array}{c}\text { Thành phần } \\
\text { tế bào }\end{array}$} & Lympho > 50\% & 87 & 70 \\
\hline & Neu $>50 \%$ & 38 & 30 \\
\hline
\end{tabular}


Tất cả bệnh nhân đều được thực hiện chọc dò dịch não tủy. Đa số có lượng Protein cao $>1 \mathrm{~g} / \mathrm{l}$ $(84,8 \%)$, đường trong dịch não tủy giảm dưới $2,2 \mathrm{~g} / \mathrm{l}$ là dấu hiệu thường gặp chiếm $73,6 \%$. Muối clo trong dịch não tủy giảm dưới $<120 \mathrm{mmol} / \mathrm{I}$ chiếm $84 \%$. Đa số bệnh nhân có số lượng tế bào trong dịch não tủy dưới 100 (tế bào/ml) chiếm $67 / 125$ (53,6\%), cũng gặp bệnh nhân có lượng tế bào dịch não tủy cao $>500$ chiếm $8 \%$. Thành phần dịch não tủy chủ yếu Lympho > 50\% $(70 \%)$. Tìm thấy bằng chứng vi khuẩn lao bằng các phương pháp nuôi cây, PCR hay GenExpert ở 88/125 trường hợp, chiếm 70,4\%.

Bảng 3: Hình ảnh tôn thương trên Cắt lớp vi tính/Cộng hưởng từ sọ não

\begin{tabular}{|c|c|c|c|}
\hline \multicolumn{2}{|c|}{ Loại tổn thương } & $\begin{array}{c}\text { Số lượng } \\
\text { (n=124) }\end{array}$ & Tỷ lệ \% \\
\hline \multicolumn{2}{|c|}{ Bình thường } & 18 & 14,5 \\
\hline \multirow{3}{*}{$\begin{array}{c}\text { Bất } \\
\text { thường }\end{array}$} & $\begin{array}{c}\text { Tăng ngấm } \\
\text { thuốc màng não }\end{array}$ & 61 & 49 \\
\cline { 2 - 4 } & U lao & 48 & 39 \\
\cline { 2 - 4 } & Nhồi máu não & 15 & 12 \\
\cline { 2 - 4 } & Giãn não thất & 99 & 80 \\
\hline
\end{tabular}

Có 18/124 bênh nhân có kết quả chup bình thường chiếm 14,5\%. Bất thường hay gặp nhất là hình ảnh giãn não thất, gặp 99/124 trường hợp chiếm $80 \%$. Tăng ngấm thuốc màng não cũng hay gặp với $49 \%$. U lao là tổn thương khu trú trong nhu mô não chiếm 39\%, nhồi máu não ghi nhân ở 12\% trường hơp.

\subsection{Kết quả điêu trị}

$$
\text { - Tử vong = Di chứng nặng }
$$$$
\text { घDi chứng nhẹ } \quad \text { Khỏi hoàn toàn }
$$

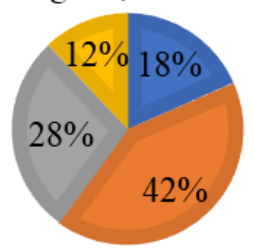

\section{Biểu đồ 1: Kết quả điều trí}

Kết quả cho thấy tỷ lệ tử vong chiểm $18,4 \%$. Nhóm sống được đánh giá mức độ di chứng dựa vào thang điểm Rankin cho thấy nhóm có di chứng nặng chiếm $41,6 \%$, di chứng nhẹ chiếm $28 \%$, khỏi hoàn toàn chiếm $12 \%$.

\subsection{Các yếu tố tiên lượng tử vong/ di chứng nặng}

Bảng 4: Phân tích đơn biến các yếu tố dư báo tiên lượng tử vong và di chứng thần kinh ở bệnh nhi lao màng não

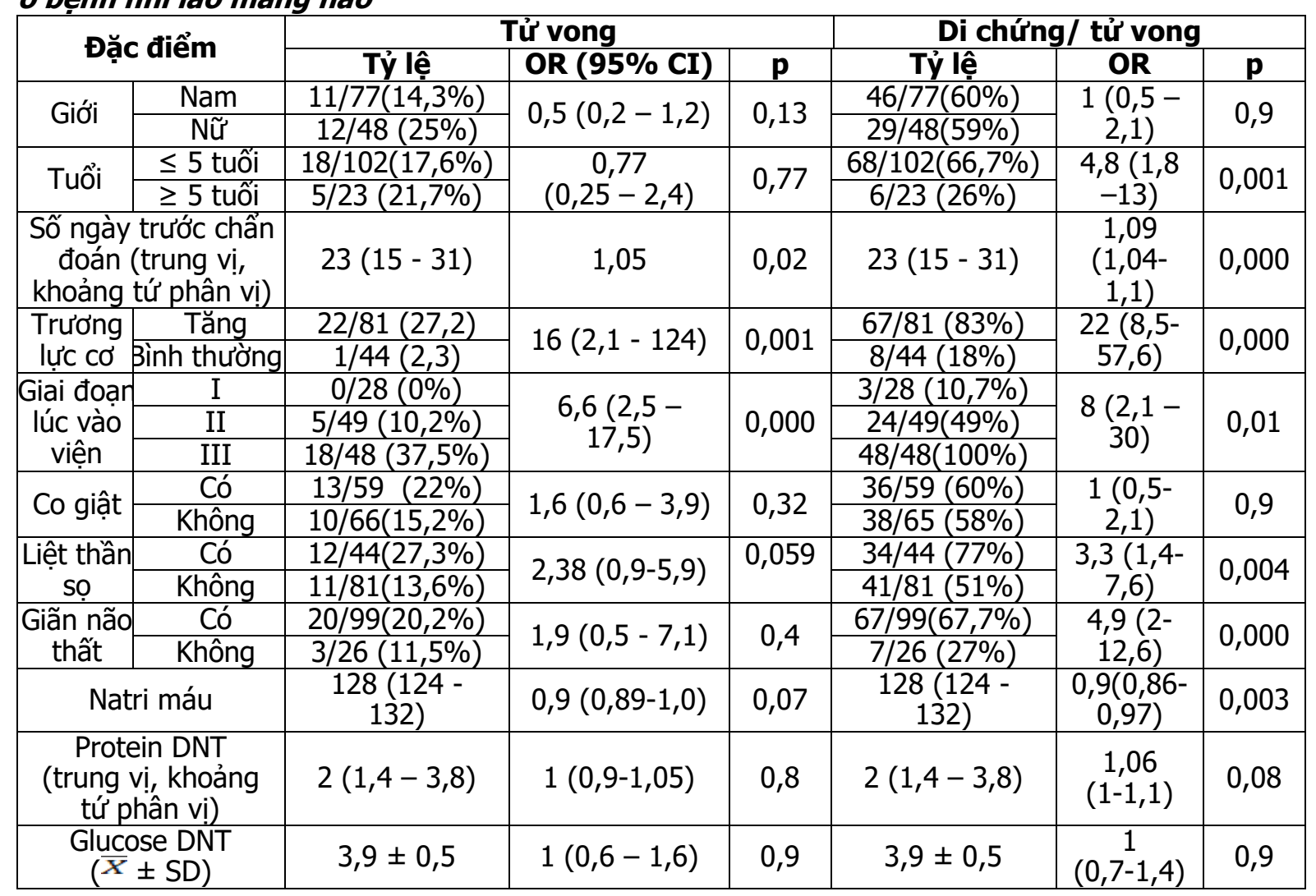


Tuổi nhỏ $\leq 5$ tuổi không phải là yếu tố tiên lượng tử vong nhưng tuổi nhỏ là yếu tố liên quan đển di chứng nặng/ tử vong. Chúng tôi cũng chỉ ra mối tương quan giữa các mức độ nghiêm trọng độ I, II, III trên lâm sàng của bệnh tại thời điểm được chẩn đoán và kết quả điều trị. Tuy nhiên mối tương quan này yếu hơn khi đưa vào phân tích đa biến với các yếu tố khác. Điều trị chậm trễ có liên quan đến tiên lượng xấu. Trong nghiên cứu của chúng tôi số ngày trước chẩn đoán có trung vị 23 ngày (tứ phân vị: $15-31$ ngày), chậm chẩn đoán 10 ngày làm tăng nguy cơ tử vong/ di chứng nặng gấp 2,3 lần $(p<0,05)$. Não úng thủy không gợi ý tăng nguy cơ tử vong nhưng liên quan đến di chứng nặng. Yếu tố tăng trương lực cớ, liệt thần kinh sọ, giãn não thất, mức độ giảm Natri máu cũng liên quan tới nguy cơ tử vong/ di chứng nặng $(p<0,05)$.

\section{BÀN LUẬN}

Bệnh viện Nhi Trung ương thu nhận điều trị cho bênh nhân lao màng não chủ yếu của khu vực Bắc Trung Bộ và toàn bộ miền Bắc, đặc biệt nhóm trẻ nhi có tình trạng nặng, cần can thiệp ngoại khoa và hồi sức. Nghiển cứu này chỉ ra những thách thức trong việc điều trị bệnh lao ở trẻ em tại khu vực này, cũng như ở trẻ em Việt Nam.

Nghiên cứu chỉ ra lao màng não trẻ em có liên quan đến tỷ lệ tử vong và di chứng đáng kể, với tỷ lệ tử vong sau kết thúc giai đoạn tấn công là $18,4 \%, 41,6 \%$ trẻ di chứng trung bình hoăc nặng. Kết quả này tương đương với những báo cáo từ các nghiên cứu khác trong và ngoài nước [3], [6]. Chúng tôi đã chỉ ra nhóm tuổi hay găp nhất là dưới 5 tuổi (44\%), xác định được nguồn lây ở 55,6\% bệnh nhân, đa số từ những người trong gia đình. Nhóm tuổi nhỏ này có nguy cơ tử vong/ di chứng nặng cao gấp 4,8 lần nhóm tuổi trên 5 (phân tích hồi quy Logistic đơn biến). Như vậy đặt ra nên tầm soát Lao tiềm ẩn ở nhóm tuổi này, là những trẻ tiếp xúc gần với người lớn được xác định Lao phổi AFB (+).

Việc thúc đẩy điều trị Lao màng não trẻ em kịp thời vẫn là một thách thức đáng kể. Trong nghiên cứu của chúng tôi, thời gian trung bình tới khi được chẩn đoán là 23 ngày, qua phân tích đơn biến nhận thấy chậm chẩn đoán 10 ngày tăng nguy cơ tử vong/ di chứng nặng gấp 2,3 lần $(p<0,05)$. Như vậy điều trị kịp thời có thể cải thiện kết quả điều trị. Quan tâm tới sự chậm trễ trong chẩn đoán và điều trị chúng tôi quan tâm tới quá trình trước khi được chẩn đoán của bệnh nhân. Có 1 số trường hợp do gia đình đưa tới bệnh viện muộn do việc tiếp cận chăm sóc sức khỏe khó khăn vì lý do kinh tế, khoảng cách. Môt số là do giai đoạn đầu biểu hiện lâm sàng mơ hồ, đặc biệt bênh nhân sốt rất ít hoặc không sốt. Bên cạnh đớ vẫn có trường hợp bỏ sót nhiễm trùng hệ thần kinh trung ương chiếm 36\%. Bệnh nhân đã được điều trị trước đó với các chẩn đoán không rõ nguyên nhân: hạ Natri máu, ngộ độc chì, não úng thủy bẩm sinh, vẹo cổ... Nhóm trẻ đã được tiếp cận với viêm màng não, thì việc tìm bằng chứng vi khuẩn lao trong dịch não tủy là khá khó khăn, phải kiểm tra nhiều lần xét nghiệm dịch não tủy. Hiện nay, tại bệnh viện Nhi trung ương, khả năng tiếp cận các xét nghiệm cận lâm sàng tiên tiến như GeneXpert, PCR lao đã được cải thiện rất nhiều. Trên thế giới đã có những nghiên cứu nhằm đưa ra giải pháp tăng cường phát hiện vi khuẩn, họ chứng minh một thể tích dịch não tủy đáng kể thích hợp ảnh hưởng tới khả năng xác nhận chẩn đoán và lấy mẫu thích hợp để tìm bệnh lao tại các địa điểm khác [7].

Hiện nay, theo Hướng dẫn chẩn đoán và điều tri của Bộ y tế, bệnh nhân Lao màng não trẻ em vẩn được hướng dẫn sử dụng liều thuốc giống như Viểm phổi. Trong nghiên cứu mô tả này chúng tôi không thể đánh giá về hiệu quả của phác đồ thuốc chống lao và liều lượng đang sử dụng. Các thử nghiệm ngẫu nhiên có đối chứng ở trẻ em đang được tiến hành để cải thiện việc điều trị bệnh lao liển quan đến thuốc mới và liều lượng thuốc đang sử dụng.

Xu hướng hiện nay với các kỹ thuật chẩn đoán hình ảnh hiện đại, dữ liệu về các biến chứng mạch máu não đã được xác định chính xác hơn, cụ thể hơn. Tác giả Soni và cộng sự đã chỉ ra Nhồi máu não xảy ra ở $57,5 \%$ bệnh nhân viêm màng não do lao có liên quan đến tăng nguy cơ di chứng nặng và tử vong. Trong nghiên cứu này chúng tôi nhận thấy việc đánh giá nhồi máu não chưa được đây đủ cho nhóm bệnh nhân này tại bệnh viện Nhi trung ương để đưa ra khuyến cáo dự phòng biến chứng này. Các nghiên cứu trên thế giới cũng chỉ ra điều trị kháng lao dường như không hiệu quả trong việc ngăn ngừa biến chứng mach máu, vai trò của corticosteroid trong việc giảm tỷ lệ tử vong hiện đã được khẳng định rõ ràng, tuy nhiên, vai trò của nó như một liệu pháp phòng ngừa biến chứng mạch máu vẫn đang được nghiên cứu. Điều quan trọng là phải biết căn nguyên chính xác của nhồi máu trong Lao màng não vì thuốc kháng tiểu cầu có thể có hiệu quả đối với nhồi máu động mạch, trong khi thuốc chống đông máu có thể có hiệu quả đối với nhồi máu tĩnh mạch [8]. 


\section{KẾT LUÂN}

Viêm màng não do lao ở trẻ em tại Bệnh viện Nhi trung ương gặp nhiều ở trẻ $\leq 5$ tuổi, có tỷ lệ tử vong và di chứng đáng kể. Chậm trễ trong chẩn đoán, tình trạng tăng trương lực cơ, mức độ nghiêm trọng trên lâm sàng (theo BMRC), tăng trương lực cơ, mức độ giảm Natri máu, giãn não thất là các yếu tố tiên lượng tử vong và di chứng thần kinh.

\section{TÀI LIỆU THAM KHẢO}

1. Global tuberculosis report 2020. <https://www.who.int/publications-detailredirect/9789240013131>, accessed: 17/10/2021.

2. Marais B.J. và Pai M. (2007). Recent advances in the diagnosis of childhood tuberculosis. Arch Dis Child, 92(5), 446-452.

3. Daniel B.D., Grace G.A., và Natrajan M. (2019). Tuberculous meningitis in children:
Clinical management \& outcome. Indian J Med Res, 150(2), 117-130.

4. Bô trưởng Bộ $Y$ tế Quyết định 4263/QĐ-BYT năm 2018 về hướng dẩn chẩn đoán, điều trị và dự phòng bệnh lao. .

5. Ge T. và Th T. (2005). Tuberculous meningitis: many questions, too few answers. Lancet Neurol, 4(3).

6. Bang N.D., Caws M., Truc T.T. và cộng sự. (2016). Clinical presentations, diagnosis, mortality and prognostic markers of tuberculous meningitis in Vietnamese children: a prospective descriptive study. BMC Infect Dis, 16(1), 573.

7. Thwaites G.E., Chau T.T.H., và Farrar J.J. (2004). Improving the Bacteriological Diagnosis of Tuberculous Meningitis. J Clin Microbiol, 42(1) 378-379.

8. Rohlwink U.K., Kilborn T., Wieselthaler N. và cộng sự. (2016). Imaging Features of the Brain, Cerebral Vessels and Spine in Pediatric Tuberculous Meningitis with Associated Hydrocephalus. Pediatr Infect Dis J, 35(10), e301-e310.

\section{ĐĂC ĐIỂM LÂM SÀNG VÀ CÂ̂N LÂM SÀNG CỦA BÊ̂NH U LYMPHO TẾ BÀ̀ B VÙNG RÌA TẠI VIÊ̂N HUYẾT HỌC-TRUYỀN MÁU TRUNG ƯƠNG}

\section{TÓM TẮT}

Mục tiêu: Mô tả đặc điểm lâm sàng, cận lâm sàng của bệnh nhân u lympho tế bào $B$ vùng rìa (MZL)tại Viện Huyết học-Truyên máu Trung ương từ tháng 1/2015 đến tháng 10/2021. Đối tượng và phương pháp: Mô tả cắt ngang trên 86 bệnh nhân MZL. Kết quả: Phát hiện cả 3 thể bao gồm MALT 73,3\%, NMZL 20,9\%, SMZL 5,8\%; trong đó vị trí thường gặp là dạ dày $(25,6 \%)$ và mắt $(24,4 \%)$. Nam nhiêu hơn nữ (58,1\% và 41,9\%). Tuổi trung bình của MALT, NMZL, SMZL lần lượt là 54,6 tuổi; 52,8 tuổi; 55,8 tuổi. Nhóm MALT có tỉ lệ gặp triệu chứng $B(7,9 \%)$, thiếu máu $(20,6 \%)$, hạch to $(1,6 \%)$, lách to $(0 \%)$ thấp hơn có ý nghĩa thống kê so với nhóm NMZL và nhóm SMZL. Nhóm MALT có tỉ lệ huyết sắc tố thấp $(20,6 \%)$, số lượng tiểu câu giảm $(4,8 \%)$, bạch câu tăng $(9,5 \%)$, rối loạn hình thái tế bào tủy $(11,1 \%)$, mật độ tế bào tủy tăng $(7,9 \%)$, xâm lấn tủy $(11,1 \%)$, Ki67 >30\% $(11,1 \%)$ thấp hơn so với nhóm NMZL và SMZL. Không có sư khác biệt về mô bênh học giữa 3 nhóm MALT, NMZL, SMZL. Kết luận: MALT là nhóm bệnh thường gặp nhất và có sự khác biệt về các biểu hiện lâm sàng và cận lâm sàng với NMZL và SMZL.

Tư khóa: MALT, NMZL, SMZL, MZL

\footnotetext{
*Trường Đại học Y Hà Nội,

**Viện Huyết học- Truyền máu Trung ương

Chịu trách nhiệm chính: Lê Quang Chiêm

Email: lequangchiem3689@gmail.com

Ngày nhận bài: 10.9.2021

Ngày phản biện khoa học: 9.11.2021

Ngày duyệt bài: 15.11.2021
}

\section{SUMMARY \\ CLINICAL AND SUBCLINICAL FEATURES OF MARGINAL ZONE LYMPHOMA (MZL) AT THE NATIONAL INSTITUTE OF HEMATOLOGY AND BLOOD TRANSFUSION}

Objectives: Todescribethe clinical and subclinical characteristics of patients with Marginal zone lymphoma (MZLs) at the National Institute of Hematology and Blood Transfusion from January 2015 to October 2021. Methods: A cross-sectional study was implemented among 86 MZLspatients. Results: All 3 types including MALT $(73.3 \%)$, NMZL $(20.9 \%)$ and SMZL (5.8\%) were found in our study; the more common affected locationswere the stomach $(25.6 \%)$ and the eyes $(24.4 \%)$. The proportion of men was higher than women (58.1\% and $41.9 \%$, respectively). The mean age of MALT, NMZL and SMZL patients were $54.6 ; 52.8$ and 55.8 years old, respectively. The incidences of B symptoms (7.9\%), anemia (20.6\%), lymphadenopathy $(1.6 \%)$, splenomegaly $(0 \%)$ in MALT group were statistically lowerthan those in NMZL and SMZL groups. The MALT group also hadthe rates of low hemoglobin concentration (20.6\%), low platelet count $(4.8 \%)$, high white blood cell count $(9.5 \%)$, myeloid cell morphological disorder $(11.1 \%)$, increased density of bone marrow cells (7.9\%), bone marrow invasion $(11.1 \%)$ and positive-Ki67>30\% (11.1\%) lower than those of NMZL and SMZL groups. There was no histopathological difference between the 3 groups of MZLs. Conclusion: MALT is the most common type of MZLs and has the differences in clinical and subclinicalfeatures in comparison with NMZL and SMZL.

Key words: MALT, NMZL, SMZL, MZL. 